\title{
6 \\ REFLEKSI PEMIKIRAN MULTIKULTURALISME BAGI DAKWAH
}

\author{
Ellyda Retpitasari dan Luluk Fikri Zuhriyah \\ FDK UINSA Surabaya \\ Email: lulukfikri@uinsby.ac.id
}

\begin{abstract}
This paper aims to discuss multiculturalism thinking from Europe and Asia, such as Bikhu Parekh, Daniel Conjanu, and Charles Taylor. Multiculturalism thinking is explored for the sake of Da'wa, or it can be called as multiculturalism preaching. This study uses literature review, and analysis of multiculturalism phenomena in the city of Surabaya. These thinkers used a number of approaches in terms of recognition politics, new identity politics, political equality with dignity, politics of difference, accommodative multiculturalism, and pragmatism. In the analysis of the Da'wa approach is divided into two, namely the structural approach and cultural approach. The structural approach refers to politics that encompasses politics of recognition, politics of new identity, politics of equality with dignity, and politics of difference. As for the cultural approach, it encompasses accommodative multiculturalism and pragmatism. Through this multicultural preaching approach it becomes an offer in overcoming the problems of preaching in multicultural societies.
\end{abstract}

Keywords: Reflections on thought, multiculturalism, da'wa.

\begin{abstract}
Abstrak: Tulisan ini bertujuan untuk membahas pemikiran multikulturalisme dari Eropa dan Asia, seperti Bikhu Parekh, Daniel Conjanu, dan Charles Taylor. Pemikiran multikulturalisme ditelaah untuk kepentingan dakwah, atau dapat disebut dengan dakwah multikulturalisme. Penelitian ini menggunakan telaah pustaka, dan analisis fenomena multikulturalisme yang ada di kota Surabaya. Para pemikir tersebut menggunakan beberapa pendekatan dengan istilah politik pengakuan, politik identitas baru, poltik kesetaraan bermartabat, politik perbedaan, multikulturalisme akomodatif, dan pragmatism. Dalam analisis pendekatan dakwah terbagi menjadi dua, yakni pendekatan struktural dan pendekatan kultural. Untuk pendekatan struktural mengacu pada politik yang melingkupi politik pengakuan, politik identitas baru, politik kesetaraan bermartabat, dan politik perbedaan. Adapun untuk pendekatan kultural melingkupi multikulturalisme akomodatif dan pragmatisme. Melalui pendekatan dakwah multicultural ini menjadi tawaran dalam mengatasi problematika dakwah pada masyarakat multikultur.
\end{abstract}

Kata Kunci: Refleksi pemikiran, multikulturalisme, dakwah.

\section{A. Background}

Indonesia merupakan salah satu negara yang kaya akan suku, agama, budaya, etnis dan bahasa. Dengan keragaman budaya ini berdampak terhadap kejadian perpecahan dan konflik. Maka diperlukan upaya yang terintegrasi dalam mempertahankan kesatuan negara yang multikultural. 
Sebagai negara paling majemuk di dunia, Indonesia memiliki jumlah penduduk lebih dari 200 juta jiwa, terdapat tidak kurang dari 300 etnis dengan identitas budaya beranekaragaman seperti lebih dari 250 bahasa yang dipakai, dan beranekaragaman kepercayaan yang diyakini. 109

Adapun perihal negara majemuk, terdapat kelebihan dan kekurangan yang terjadi di Indonesia. Kekayaan kemajemukan seperti keragaman budaya dan etnis dapat digunakan sebagai kekayaan bangsa, namun dapat menjadi celah munculnya konflik dalam masyarakat.

Sampai tahun 2018, masih juga terjadi konflik dan kasus intoleransi dan kekerasan beragama. Institut Setara mencatat ${ }^{110}$ sepanjang tahun ini terdapat 7 (tujuh) kasus, yaitu: pengrusakan pura di Lumajang oleh orang tak dikenal, penyerangan terhadap ulama di Lamongan, perusakan masjid di Tuban, ancaman bom di kelenteng Kween Tan Koen Karawang, serangan gereja Santa Lidwina Sleman, persekusi terhadap Bikhsu di Tangerang, dua serangan brutal terhadap tokoh Islam ${ }^{111}$

Beberapa fenomena terkait dengan kekerasan dan intoleransi sampai munculnya aksi terorisme adalah bagian dari paham radikalisme yang muncul di Indonesia. Terorisme yang marak terjadi dengan latar belakang ideologi tertentu, berawal dari intoleransi yang kemudian mengalami radikalisasi hingga berujung pada aksi bom bunuh diri, penyerangan, dan kekerasan lainnya. Terjadinya pengeboman di tiga tempat ibadah di Surabaya beberapa waktu lalu merupakan aksi akibat paham radikal yang sudah terpapar pada oknum pengeboman.112 Kelompok Islam ini cenderung memahami Islam secara tekstual, yang akhirnya mereka kehilangan untuk berempati, dan tidak mempertanggung jawabkan apapun yang dikatakan dan dilakukan.

Selain itu, pada ranah dakwah mereka melakukan kegiatan dakwah yang saling menyakiti baik dalam perkataan maupun perbuatan antara satu dengan yang lain, tidak toleran, merasa kelompoknya paling benar sendiri, dan menyalahkan pihak lain yang berbeda paham dengannya. Akhirnya, problematika dakwah saat ini munculnya orang-orang dengan mudah memberi label kelompok lain dengan sebutan bid'ah, kafir, dan murtad.

Begitu kuatnya arus radikalisme ini, menjadikan kondisi harmoni dalam kehidupan sosial terguncang. Adanya isu radikalisme yang menyusup dalam dakwah yang dibawa oleh kelompok atau individu dengan paham radikal, konflik antar agama dan etnis menjadikan dakwah yang bernuansa toleransi dan moderasi, dan saling memahmi perlu digalakkan kembali.

Maka untuk mewujudkan harmonisasi dalam keberagaman budaya dan agama di Indonesia, muncullah dakwah multicultural, dimana konsep ini digagas sebagai angin segar dalam berdakwah tanpa merusak tatanan sosial dan budaya yang ada di masyarakat.

109 Maqbul Arib. "Dakwah Tengah Keragaman dan Perbedaan Umat Islam" Jurnal Dakwah Tabligh. 15.1(2014): 38

110 SETARA Institute for Democracy and Peace adalah sebuah lembaga swadaya masyarakat yang berbasis di Indonesia yang melakukan penelitian dan advokasi tentang demokrasi, kebebasan politik dan hak asasi manusia. ${ }^{[1]}$ SETARA Institute adalah organisasi penelitian dengan penelitian intinya yang berfokus pada menjawab kebutuhan aktual masyarakat. Dibentuk pada tahun 2005, SETARA Institute dimaksudkan sebagai respons terhadap maraknya fenomena fundamentalisme, diskriminasi dan kekerasan atas nama agama dan moralitas di banyak bidang yang mengancam pluralisme dan hak asasi manusia di Indonesia. SETARA Institute bekerja di ruang sekuler (hukum berbasis hak asasi manusia dan konstitusi) dan tidak melakukan penelitian yang menembus ke teologi agama. SETARA Institute adalah perintis pembela kebebasan beragama di Indonesia. Organisasi ini mempromosikan kebebasan sipil dan perubahan kebijakan untuk mendorong pluralisme dan hak asasi manusia.

https://id.wikipedia.org/wiki/Setara Institute (diakses tanggal 10 September 2019)

111 https://www.idntimes.com/news/indonesia/rochmanudin-wijaya/linimasa-kasus-intoleransi-dankekerasan-beragama-sepanjang-2/full (diakses 10 September 2019)

112 Bom bunuh diri terjadi di tiga gereja pada tanggal yang sama 13 Mei 2018, bom pertama meledak sekitar pukul 07.30 WIB di Gereja Katolik Santa Maria Tak Bercela di Jalan Ngagel Madya Utara, Surabaya. Selang sekitar lima menit kemudian bom kedua meledak di gereja Pantekosta di jalan Arjuno, dan tidak lama kemudian bom meledak di gereja GKI di jalan Diponegoro Surabaya.

https://www.bbc.com/indonesia/indonesia-44097913 (diakses, 10 September 2019). 
Max Muller menyatakan bahwa agama dakwah diartikan sebagai agama yang berusaha menyebarluaskan kebenaran dan mengajak orang-orang yang belum mempercayainya sehingga kebenaran terwujud dalam pikiran, kata-kata, perbuatan dan tertanan dalam jiwa setiap orang. ${ }^{113}$ Dalam Islam, dakwah merupakan sebuah sarana mengajak seseorang untuk menjadi lebih baik, karena dakwah berfokus pada amar ma'ruf nahi munkar.

Sedangkan untuk pengertian multicultural berawal dari dua kata "multi" dan "kultural", dimana "multi" berarti banyak, beragam, bervariasi, bermacam-macam, sedangkan "kultur" berarti budaya. ${ }^{114}$ Dapat disimpulkan bahwa multicultural adalah kehidupan masyarakat yang beragam dengan berbagai perbedaan budaya.

Dengan demikian dakwah multicultural merupakan model pendekatan dakwah kepada seluruh lapisan masyarakat beragam, atau bisa diartikan dakwah multicultural. Dakwah multikultural merupakan dakwah yang berfokus pada penyampaian pesan-pesan Islam dalam konteks keragaman dalam masyarakat dengan mencari titik temu tentang hal yang disepakati, dihargai, dan ditoleransi. ${ }^{115}$ Dalam pelaksanaan dakwah, jika dakwah sendiri tidak menanamkan nilai budaya yang sesuai, maka dapat ditolak dan ditinggalkan oleh umatnya. Dakwah dengan membimbing, mengayomi dan mempertahankan keragaman budaya. Hal inilah yang mendasari peneliti untuk lebih menelaah dakwah multicultural dengan refleksi pemikiran multikulturalisme untuk kepentingan berdakwah.

\section{B. Review Teoretis}

\section{Dakwah}

Da'wah secara lughawi berasal dari bahasa Arab yang memiliki arti seruan, panggilan, dan undangan. Adapun menurut istilah, dakwah adalah menyeru ataupun mengajak manusia dalam upaya melakukan suatu kebaikan dan menurut petunjuk dalam Islam, menyeru untuk berbuat kebajikan dan melarang perbuatan munkar yang dilarang oleh Allah Swt dan Rasul-Nya, hal ini sebagai wujud untuk mendapatkan hadiah berupa kebahagiaan di dunia dan akhirat. 116

Lain halnya dengan Kamus Besar Bahasa Indonesia, menyatakan bahwa dakwah memiliki arti yakni penyiaran atau propaganda. Maka dakwah berarti penyiaran agama di kalangan masyarakat berupa seruan, guna untuk memeluk, mempelajari dan mengamalkan ajaran agama. Maka dakwah dapat diartikan sebagai seruan atau ajakan untuk mempelajari dan mengamalkan ajaran agama. ${ }^{117}$ Adapun untuk tujuan dakwah adalah sesuatu yang hendak dicapai dalam pelaksanaan dakwah, sebagaimana merealisasikan ajaran-ajaran Islam. wujud realisasi diantaranya perubahan seseorang, kelompok dan masyarakat atau biasa disebut dengan amar ma'ruf nahi munkar. 118

Selain amar ma'ruf nahi munkar, tujuan dakwah dapat dirinci menjadi beberapa hal seperti (a) mengajak untuk bertakwa dan beribadah hanya kepada Allah; (b) mengajak untuk berbuat baik dan meninggalkan perbuatan tercela; (c) mempererat tali silaturrahmi antara da'I (orang yang menyampaikan pesan dakwah) dan mad'u (orang yang menerima pesan dakwah); (d) sebagai tempat dalam menyebarkan, mencari, dan memperdalam ilmu-ilmu keislaman; (e) sebagai tempat mengutarakan dan mencari solusi atas permasalahan di dunia sekaligus sebagai bekal amal ibadah

113 BBC. Islam akan menjadi 'agama terbesar pada 2075. https://www.bbc.com/indonesia/majalah39510081, (diakses pada 06 September 2019).

${ }^{114}$ Zainal huda. "Dakwah Islam Multikultural (Metode Dakwah Nabi SAW kepada Umat Agama Lain)". Jurnal RELIGIA 19.1 (2016): 95.

115 Zainal huda, "Dakwah Islam Multikultural (Metode Dakwah Nabi SAW kepada Umat Agama Lain)". Jurnal RELIGIA 19.1 (2016): 96.

${ }^{116}$ Abdul Aziz Ahmad, “Dakwah, Seni dan Teknologi Pembelajaran." Jurnal Dakwah Tabligh114.1: 76.

117 Tim Penyusun Kamus Pusat Pengembangan dan Pembinaan Bahasa, Kamus Besar Bahasa Indonesia. (Jakarta: Balai Pustaka, 1990), 307.

118 Muklis, "Strategi Dakwah Al Bayanuni (Analisis Strategi Muhammad Abu Fatah Al Bayanuni Dalam Kitab Al Madkhal Ila Ilmi Dakwah." Islamic Communication Journal. 3.1 (2018): 75-76. 
di akhirat kelak; dan (f) sebagai media dalam menyebarkan sebuah keyakinan, aliran dan memperluas jaringan. 119

\section{Multikulturalisme}

Multikulturalisme merupakan sebuah paradigma yang memberikan kesepakatan adanya kesetaraan antara ekspresi budaya yang plural. Wujud gagasan ini berupa kesadaran sosial yang ada dalam aspek kehidupan sosial masyarakat terdapat beragam budaya. ${ }^{120}$ kesadaran ini memiliki nilai sebuah tindakan yang baik dan benar, sebagaimana contoh penghargaan, penghormatan, perhatian, kasih sayang serta cinta dan pengakuan terhadap perbedaan antara individu yang satu dengan yang lain maupun kelompok satu dengan yang lain.

Musa Asy'ayrie menyatakan bahwa multikulturalisme merupakan kearifan dalam melihat keanekaragaman budaya, dimana budaya dijadikan sebagai realitas fundamental dalam kehidupan bermasyarakat. ${ }^{121}$ sedangkan pendapat Everett M Rogers dan Thomas M. Steinfatt menyatakan bahwa multikulturalisme suatu bentuk pengakuan bahwa beberapa kultur yang beranekaragam dapat eksis dalam lingkungan yang sama dan tidak merugikan antara satu dengan yang lain. ${ }^{122}$ pada dasarnya multikulturalisme merupakan sebuah padangan dunia (worldview), dengan diaplikasikan pada realitas keragaman, pluralitas dan multicultural dalam setiap aspek kehidupan masyarakat. ${ }^{123}$ Pemahaman lain multikulturalisme terkait pandangan dunia yang kemudian diwujudkan dalam sebuah istilah "politics of recognition". 124

Dikutip dari Nawawi, T Raka Joni menyatakan bahwa ada empat poin yang saling berkaitan untuk mewujudkan keragaman. Diantaranya pertama, personal level dalam hal ini proses multikulturalisme di mulai dari pengasuhan (parenting) dalam keluarga dan dibiasakan dengan menghormati keragaman budaya. Kedua, organization level, pendidikan formal dan lapangan kerja memberikan tempat untuk saling menghormati dan menghargai keragaman budaya. Ketiga, societal level dimana dalam kehidupan bermasyakat dapat berlanjut dengan baik dengan mengutamakan perhormatan kepada keragaman. Keempat, system level, peraturan yang ditetapkan negara seperti melalui perundang-undangan dapat menanamkan kesadaran multicultural. 125

\section{Metode Kajian}

Kajian ini berawal dari pengkajian terhadap pemikiran multikulturalisme dan implementasinya di beberapa negara. Dengan melihat beberapa realitas aktual terkait problem kemajemukan dan keragaman dan mencoba untuk menawarkan solusi melalui dakwah multikultural sebagai upaya untuk menjaga keharmonisan kehidupan sosial beragama dalam negara yang plural dari sisi agama, budaya, suku, etnis dan keragaman kepentingan. Analisis ini dilakukan dengan merujuk hasil pemikiran multikulturalisme, dengan literature terkait dakwah di Indonesia dalam bentuk text book baik tercetak maupun elektronik (online melalui internet).

\section{Temuan}

\section{Pemikiran Multikulturalisme Daniel Conjanu}

Daniel Conjanu merupakan seorang dosen dari fakultas Ilmu Politik, Sastra dan Komunikasi di Valahia University of Targoviste di Rumania. Rumania memiliki kelembagaan dan dinamika

\footnotetext{
119 Thomas W. Arnold, The Preaching of Islam (terj. Sejarah Dakwah Islam), (Jakarta: Widyaja, 1985$), 1$.

120 Supardi Suparlan, Menuju Masyarakat Indonesia yang Multikultural (Jakarta: Gramedia, 2002) 13.

121 Gina Lestari." Bhinneka Tungga Ika: Khasanah Multikultural Indonesia di Tengah Kehidupan Sara.” Jurnal Pendidikan Pancasila dan Kewarganegaraan 28.1 (2015): 33.

${ }^{122}$ Imam Amrusi Jailani. "Dakwah dan Pemahaman Islam di Ranah Multikultural”. Jurnal Walisongo 22.2 (2014):1 415

123 Thomas La Belle \& Christopher Ward, Multiculturalism and Education (Albany: SUNY Press, 1994 ), 53.

124 Charles Taylor, Multiculturalism: Examining The Politics of Recognition (Princeton: Princeton University Press, 1994), 35.

125 Nawawi, "Dakwah Dalam Masyarakat Multikultural." Jurnal KOMUNIKA: Dakwah dan Komunikasi 6. 1, (2012): 4-5.
} 
perilaku dari proses sosial yang terjadi sejak 1989. Negara ini, merupakan salah satu negara terbesar di Eropa Timur anggota Uni Eropa (UE). ${ }^{126}$ Dalam kajian multikulralisme Daniel Conjanu melakukan riset terkait keanekaragam budaya dan politik identitas baru. Adapun pemaparannya sebagai berikut:

\section{a. Relevansi Politik pada Identitas Budaya}

Pembahasan politik identitas baru sebagai kajian untuk memecahkan problematika identitas yang ada pada masyarakat postmodern yang terus bergerak dinamis, hal ini mencakup dua identitas, yakni identitas individu dari latar belakang dan sejarah pribadi dan identitas kolektif dari komunitas etno-kultural dan tradisi budaya. Transisi menuju modernitas awal juga berarti transisi moral dan perilaku dari praktik yang terkait dengan pengakuan kehormatan kepada yang terkait dengan pengakuan martabat. Dalam hal ini mencakup martabat manusia dalam masyarakat modern egaliter, dengan menjunjung tinggi persamaan derajat setiap manusia. Dimana sebelumnya masyarakat cenderung hierarkis yang menganggap keanekaragaman etnis dan budaya mengandung unsur ketidaksetaraan.

Pengakuan terhadap keragaman budaya tidak dapat diaplikasikan secara baik bila masih terdapat prasangka dan rasa curiga. Karena pada dasarnya keragaman budaya merupakan suatu keniscayaan yang wajib diakui keberadaannya. Identitas, khususnya, yang dari komunitas budaya, perlu pengakuan publik, oleh karena itu hak mendasar dari budaya dan komunitas etno-budaya untuk mengekspresikan kekhususan mereka dan mempertahankan kekhususan ini.

\section{b. Keragaman budaya dan Politik pengakuan}

Pengakuan publik atas identitas budaya dapat diartikan sebagai hak alami individu yang terkait dengan kebebasan berbicara. Menjunjung hak khusus kelompok minoritas etno-budaya, melalui perlakuan khusus seperti melestarikan kekhususan, tradisi dan identitas budaya. Hal ini sebagai upaya pelestarian keanekaragaman hayati dan budaya. Budaya dalam konteks pernyataan Daniel Conjanu adalah lingkungan spiritual, khusus untuk kelompok manusia dengan asal-usul yang sama, yang memungkinkannya untuk bereproduksi sendiri dan bertahan dari waktu ke waktu, lingkungan yang menawarkan kepada anggota komunitas visi spesifik dunia, cara pemahaman, nilai-nilai dan perilaku spesifik, cara berekspresi dan berkreasi yang berbeda dari perilaku anggota budaya lain.

\section{c. Pragmatisme dan Politik Identitas Baru}

Realitas politik dari koeksistensi kelompok-kelompok budaya di dunia saat ini menuntut pemikiran ulang atas teori politik. Pluralisme dari nilai-nilai dan bentuk kehidupan memperjelas ketidakmungkinan mencari konsensus tidak hanya dalam hal nilai, tetapi juga prinsip. Identitas budaya mulai dianggap sebagai unsur penentu martabat manusia bersama dengan hak-hak individu yang alami, yang dipahami terutama sebagai hak-kebebasan. Dengan demikian, masyarakat yang tidak mengakui identitas budaya dipersepsikan dan ditafsirkan dalam konteks saat ini sebagai bentuk penindasan yang mencolok yang bahkan dapat dibandingkan dengan pelanggaran hak-hak universal kebebasan hati nurani dan ekspresi. Penghormatan terhadap martabat individu manusia juga mencakup pengakuan atas dimensi konkret mereka sebagai makhluk sejarah yang berutang cara hidup kepada tradisi, kelompok etnis, dan budaya asal tertentu.

Membahas ruang publik multicultural tidak akan memuncul from the ideal dari konsensus, tapi dari kebutuhan untuk hal hidup bersama pragmatis yang dirundingkan mempertimbangkan nilai utama pemandu lifestyles dan unsur dari perilaku tersebut mengekspresikan lebih baik golongan kesukuan.

Ketentuan dari hal hidup bersama akan disesuaikan ke hubungan kalimat dan akan melibatkan pengenalan timbal balik, kepentingan dengan perbedaan budaya tidak hanya kesamaan dari hak. Prinsip dari hal hidup bersama dan bantuan kerjasama akan mengekspresikan satu modus

126 Sergiu Gherghina, Political Dynamic in Post Communist Romania, The Romanian Political System After 1989 Sudosteuropa 63.1 (2015): 6. 
vivendi dan tidak memisahkan prinsip. Ketentuan hal hidup bersama akan diadopsi keberadaan berharga dan tidak terpisah dari mereka, di belakang satu cadar simbolis dari kejahilan. Ini menyiratkan satu memikirkan ulang dari hubungan di antara ruang publik dan bagian privasi.

Keaneka ragaman kesukuan dan klaim dari budaya dan politik penentuan diri, bahkan otonomi wilayah, dirumuskan oleh minoritas sejarah, telah menginduksi negara nasional yaitu ketidakmampuan integrasi sosial. Sebagian orang pengaruhi keaneka ragaman budaya sebagai satu sumber ketidakstabilan dan konflik, yang lain berpikir bahwa hidup bersama dan dialog masih memiliki otonomi. Saat group menginginkan tidak hanya dimaklumi kecuali juga dikenal pada ruang publik multikultural dan dihormati untuk ketegasan mereka,

Politik Identitas Baru harus membedakan di antara individu dan identitas kolektif, di antara identitas warisan dan yang memilih, di antara identitas budaya dan gender, rasial, identitas profesional atau identitas keagamaan, ini juga harus menetapkan kriteria untuk aplikasi dengan hak budaya pada hubungan dari minoritas nasional dengan populasi mayoritas atau di antara orang pindahan dan penerimaan negara. ${ }^{127}$

\section{Pemikiran Multikuluralisme Charles Taylor}

Charles Taylor adalah seorang filsuf, politisi, dan aktivis politik Kanada. Ia tinggal di kota campuran antar etnis Montreal, Quebec, tempat ia mengajar filsafat di Universitas McGill. Sebagai seorang tokoh sentral, secara politis maupun filosofis dalam budaya Quebec yang rumit, Taylor hadir sebagai seorang sosok yang vokal sehingga dikenal luas dalam upaya legislatif untuk mempertahankan kelompok masyarakat yang berbeda.

Sebelum masuk pada tahun pemikiran Charles Tylor, maka terlebih dahulu mengetahui situasi Quebec. Quebec secara konstitusional ditunjuk oleh pemerintah federal sebagai kelompok masyarakat yang berbeda. Upaya untuk mempertahankan warisan budaya yang berbeda berada di pusat referendum mengenai pemisahan dari Kanada, pembatasan pilihan sekolah, dan undangundang yang melarang penggunaan Bahasa Inggris dalam ranah publik.

Terdapat pokok bahasan pemikiran multikulturalisme Charles Taylor:

\section{a. Multikulturalisme}

Taylor memberikan sumbangsih pemikiran tentang multikulturalisme dan pembentukan identitas. Multikulturalisme meurpakan sebuah pengakuan yang adil bukan hanya rasa hormat yang kita miliki pada orang lain, akan tetapi sebuah kebutuhan manusia yang vital. Sebagaimana contoh Taylor dalam memperjuangkan permohonan mahasiswa kulit berwarna di kampus, dikarenakan pihak kampus berpendapat bahwasannya institusi tidak mengenali cara mereka, mencerminkan pengalaman mereka, atau menyambut perbedaan budaya mereka.

Permintaan pengakuan paham multikulturalisme yang diidentifikasi oleh Taylor diperlihatkan di kampus-kampus dengan meningkatnya perselisihan rasial, perubahan dalam kurikulum, dan penambahan jumlah mahasiswa kulit berwarna. Sehingga solusinya menurut Taylor untuk tantangan menciptakan suasana komunikasi multikultural di lingkungan terutama dalam ranah perguruan tinggi adalah dialog.

\section{b. Politik Kesetaraan Martabat}

Politik kesetaraan bermartabat mengakui keunikan identitas yang dimiliki semua orang. Melihat politik seperti itu berdasarkan pada tradisi individualisme yang paling bersemangat, Taylor menggambarkan sejenis kesamaan universal di mana politik kesetaraan bermartabat secara teoretis meratakan lapangan peluang, akses, dan masalah keadilan. Sehingga terlepas dari gender, ras, ataupun etnis, menurut politik kesetaraan bermartabat akan diberikan hak dan payung hukum yang identik. Di Amerika Serikat, hak-hak ini didefinisikan dalam "Bill of Right" dan UU Hak Sipil.

Meskipun banyak birokrat di perguruan tinggi mengakui bahwasannya dalam praktiknya mereka bergumul dengan isu-isu yang jauh melampaui asumsi sederhana tentang kesetaraan bermartabat, kebijakan dan praktiknya kampus tetap terus memasukkan unsur buta warna.

${ }^{127}$ Daniel Conjanu. Cultural Diversity and The New Politics of Identity. RSP. No 50 (2016): 31-40. 
Prosedur standar yang digunakan dalam sistem disiplin (proses yang sesuai) berupaya memperlakukan semua mahasiswa dengan sama tanpa memandang latar belakang atau keadaan historis. Perdebatan saat ini tentang kurikulum inti membuat klaim untuk universalitas teks-teks tertentu. Kriteria tradisional (ketegasan, gaya penentu, kemampuan untuk menuntut rasa hormat) yang digunakan untuk perekrutan staf diterapkan tanpa memperhatikan etnis, ras, ataupun pengalaman budaya para kandidat. Para mahasiswa memanfaatkan potensi dari kesetaraan martabat ketika mereka membentuk serikat mahasiswa kulit putih misalnya, membuat tuduhan diskriminasi terbalik, dan mengekspresikan kemarahan pada "hak istimewa" yang diberikan kepada mahasiswa kulit berwarna.

\section{c. Politik Perbedaan}

Politik perbedaan menekankan komunalisme atau asosiasi dengan suatu kelompok. Politik perbedaan mengakui keunikan suatu kelompok (perbedaan menonjol mereka dari orang lain). alihalih memiliki ciri-ciri umum sebagai sumber martabat mereka, martabat manusia lebih banyak diperoleh, jika tidak lebih dari apa yang membuat mereka berbeda dari orang lain.

Politik perbedaan tidak mengasumsikan bahwa setiap orang berasal dari bidang yang sama. adapun hal ini, individu berusaha untuk secara aktif menyamakan bidang yang dibuat tidak hanya merata pada keadaan budaya dan sejarah. Sehingga dengan demikian untuk mencapai kesetaraan dan keadilan melalui perguruan tinggi, upaya advokasi dari pihak birokrat, fakultas, dan mahasiswa. Di kampus, taktik leveling mengambil bentuk tindakan afirmatif, keuangan diferensial, dan proses penerimaan yang mempertimbangkan situasi yang berbeda. Birokrat perguruan tinggi yang membaca buku Taylor akan mengakui politik perbedaan sebagai sebuah filosofi yang menggaris bawahi banyak inisiatif keanekaragaman mereka sendiri.

Taylor secara aktif dan vokal mendukung penekanan komunalisme atas individualisme dalam situasi di mana kelangsungan hidup kebudayaan dipertaruhkan. Tanpa jenis tuduhan yang menimbulkan rasa bersalah yang begitu sering menyertai diskusi tentang keistimewaan individu yang dicapai dengan mengorbankan anggota kelompok lainnya. Sehingga Taylor meminta agar anggota masyarakat yang istimewa mempertimbangkan untuk melepaskan beberapa penekanan yang mereka lakukan pada individualisme demi kepentingan komunitas atau grup. ${ }^{128}$

\section{Pemikiran Multikulturalisme Bikhu Parekh}

Bikhu Chotalal Parekh atau biasa dipanggil dengan nama Bikhu Parekh merupakan ahli teori politik terkemuka di Inggris dan anggota aktif di House of Lords. Sebagai pelopor konsep tentang multikulturalisme, hak dan tanggung jawab kolektif dan masalah sosial budaya yang telah mempengaruhi tata kelola di Inggris, pandangan politik Parekh telah memberi pandangan politik tanpa mengintervensi dan dapat toleran, di mana orang-orang dari berbagai etnis dapat hidup dalam harmoni.

Bikhu Parekh menyatakan perspektif pluralis tentang keanekaragaman budaya, hal ini disebut dengan multikulturalisme akomodatif, dimana masyarakat plural, memiliki kultur dominan membuat penyesuaian-penyesuaian dan akomodasi tertentu bagi kebutuhan kultural kaum minoritas. Masyarakat multicultural akomodatif memiliki ciri diantaranya merumuskan dan menerapkan undang-undang, hukum, dan ketentuan-ketentuan yang sensitive secara cultural, dan memberikan kebebasan kepada kaum minoritas untuk mempertahankan dan mengembangkan kebudayaan mereka, sebaliknya kaum minoritas tidak menantang kultur dominan, fenomena ini dapat dijumpai di negara Eropa seperti Inggris, Perancis, dan beberapa negara lainnya. ${ }^{129}$

\footnotetext{
${ }^{128}$ Charles Taylor, Multiculturalism: Examining The Politics of Recognition (Princeton: Princeton University Press, 1994).

129 Bikhu Parekh. Rethinking Multikulturalism: Cultural Diversity and Political Theory. (Harvard University Press, 2002).
} 


\section{E. Pembahasan}

\section{Pemahaman Dakwah Multikultural}

Aktivitas dakwah dilakukan untuk menjamin keselamatan fisik warga negara secara individual, hak warga untuk melindungi keluarga dan keturunan. Menurut Sjahudi Siradj, dikutip Ali Aziz menyatakan bahwa pendekatan dakwah terbagi menjadi tiga yakni, pendekatan budaya dan bahasa, pendekatan pendidikan, dan pendekatan psikologis. ${ }^{130}$ Dalam konteks dakwah multicultural maka pendekatan -pendekatan tersebut dapat diterapkan sebagaimana contoh penggunaan budaya dan bahasa sebagai alat komunikasi dalam menyampaikan pesan dakwah.

Selain itu pendekatan dakwah dalam masyarakat dapat disimpulkan menjadi dua pendekatan, yaitu melalui pendekatan structural dan pendekatan cultural. 131 pendekatan structural merupakan pendekatan melalui kekuasaan atau jalur politik. Adapun pendekatan cultural merupakan pendekatan dengan jalur non politis, seperti pemberdayaan dalam bidang sumber daya manusia dan proses penegakkan hukum. Dalam konteks pemikiran multikulturalisme dari barat, maka ada keterkaitan dengan pemaparan pendekatan dakwah structural, yang mana dalam multikulturalisme ditekankan juga melalui beragam hal, seperti politik yang terbagi menjadi politik pengakuan, politik identitas baru, politik kesetaraan martabat dan politik perbedaan. Sedangkan dalam pendekatan secara cultural maka dapat diketerkaitkan dengan multikulturalisme akomodatif, dan pragmatism.

Pemahaman multicultural dengan pendekatan cultural maupun structural pada masyarakat guna untuk menghilangkan prasangka, dan mengenal perbedaan, sehingga dapat saling menghargai dan menghormati di dalam ruang masyarakat plural. Kesadaran multikulturalisme berkembang dengan permasalahan dalam HAM, dan diskriminasi rasial di negara-negara barat seperti Eropa. Maka toleransi terhadap budaya seperti adat istiadat, bahasa, agama, dan penggunaan seni menjadi salah satu aspek penentu keberhasilan dalam berdakwah. dakwah multicultural dengan menghargai nilai budaya, agama, dan adat istiadat setempat, bukan melalui pemaksaan, menakut-nakuti, dan intimidasi, karena ketiga cara ini bukan termasuk aspek dakwah dalam Islam, dimana Islam sebagai agama yang damai.

\section{Analisis Dakwah Multikultural di Kota Surabaya}

Adapun ditelaah dalam konteks fenomena yang terjadi di Indonesia sebagai negara yang multicultural, dalam hal ini peneliti menganalisis kondisi di Surabaya, dimana Surabaya sebagai kota besar kedua setelah Ibukota DKI Jakarta. Sebagai kota besar, Surabaya memiliki beragam perbedaan budaya, terdiri dari beberapa suku, agama, dan etnis. Tersebar mulai dari etnis Tionghoa hingga etnis arab ada di Kota Surabaya sendiri. Adapun terkait agama, terdapat beberapa agama yang dianut, mulai dari Islam, Kristen, Kong $\mathrm{Hu}$ Chu, Budha, dan Hindu, selain itu juga terdapat makam umat dari agama Yahudi yang merupakan bekas peninggalan sejarah zaman penjajahan.

Dalam pendekatan dakwah structural dimana dalam hal ini melingkupi beberapa kajian diantaranya:

\section{a. Politik Pengakuan}

Menurut Daniel Conjanu, Politik pengakuan menekankan pada hubungan hak individu, seperti dalam konsep dakwah multicultural, seorang muslim atau muslimah dalam berdakwah ataupun menjalankan kehidupan sehari-hari hendak menghargai kelompok minoritas etno-budaya melalui pemahaman nilai-nilai dan perilaku sebagai upaya pelestarian keanekaragaman hayati dan budaya. Hal ini terlihat ketika berada di kawasan makam Sunan Ampel Surabaya, terdapat beberapa perbedaan budaya, mulai dari Tionghoa, Arab, Suku Jawa dan Suku Madura. Makan Sunan Ampel yang dikelola pemerintah sebagai salah cagar budaya di Surabaya memiliki kebermanfaatan, meskipun terdapat birokrasi politik pemerintah dalam segi pengelolaan, namun juga memiliki manfaat untuk masyarakat hidup bersama dan saling berkerjasama.

130 Ali Aziz. Ilmu Dakwah Edisi Revisi (Jakarta: Kencana, 2004), 347.

${ }^{131}$ Ali Aziz. Ilmu Dakwah Edisi Revisi (Jakarta: Kencana, 2004), 348. 


\section{b. Politik Identitas Baru}

Politik identitas baru menelaah tentang hak individu manusia sebagai makhluk sejarah yang mempunyai tradisi, kelompok etnis, dan budaya asal. Seperti diketahui di Surabaya sendiri terdapat beberapa tempat ibadah bersejarah dan makam bersejarah yang mana tidak hanya dari satu agama atau etnis, tetapi beragam. Hal ini dapat diketahui dari Masjid Raden Rahmat, Masjid Peneleh, Masjid Cheng Hoo Surabaya, Pagoda Kenjeran, Makam Kembang Kuning (makam dari masa kolonial Belanda yang terdiri dari beragam etnis, dan agama).

\section{c. Politik Kesetaraan Martabat}

Politik kesetaraan bermartabat membahas tentang pengakuan hak-hak dan kesetaraan. Dakwah multicultural memberi pengertian kesetaraan, hal ini dapat terlihat ketika fenomena yang ada di Masjid Cheng Hoo, yang mana peneliti telaah terdapat beragam orang yang beribadah disana, tidak hanya dari kulit putih maupun kulit sawo matang, dan kulit coklat, namun sang Da'I ataupun pengelola masjid tetap menghargai hak-hak masyarakat untuk beribadah di Masjid Cheng Hoo Surabaya, meskipun masjid tersebut mendapatkan donatur dan keuangan sebagian besar dari etnis Tiong Hoa.

\section{d. Politik Perbedaan}

Politik perbedaan, dalam hal ini menekankan pada keunikan suatu kelompok atau perbedaan menonjol dari orang lain, atau dengan penekanan perilaku individualism demi kepentingan komunitas atau grup. Dalam konteks dakwah multicultural, segala sifat-sifat individualism baik da'I maupun mad'u harus diredam, demi sebuah kepentingan dan keberlangsungan kehidupan yang damai.

Sedangkan dalam pendekatan dakwah cultural melingkupi beberapa hal diantaranya:

\section{a. Multikulturalisme akomodatif}

Bikhu Parekh menuturkan multikulturalisme akomodatif, merupakan suatu pemikiran dimana masyarakat plural saling menghargai, yang mana kebebasan kepada kaum minoritas untuk mempertahankan, namun tidak menantang kultur dominan yang ada. Adapun fenomena yang terjadi Surabaya, sebagian besar menganut agama Islam, sedangkan minoritas terdapat beberapa agama, dari Hindu, Budha, Kristen, Katholik, dan Kong Hu Chu. Maka, seperti yang kita ketahui agama minoritas ini tidak pernah menantang agama mayoritas yang ada di Surabaya. Sama halnya dengan suku yang dominan di Surabaya yakni Suku Madura dan Suku Jawa, sedangkan minoritas terdapat suku batak, suku minang, dan lain-lain, tetapi masyarakat tetap saling menghargai dan toleransi antara minoritas dengan mayoritas.

\section{b. Pragmatism}

Sifat pragmatism ditekankan dalam masyarakat multicultural, bukan sifat idealism. Pragmatisme ini dapat diaplikasikan dalam segala aspek kehidupan, salah satunya dalam berdakwah, seorang da'i maupun mad'u harus memiliki sifat pragmatisme, bukan sifat idealisme.

\section{F. Kesimpulan}

Islam sebagai agama rahmatan lil 'alamin, dapat terwujud dalam dakwah multicultural yang memiliki prinsip damai, persuasive, dan menghargai nilai-nilai budaya, adat dan tradisi masyarakat yang berlaku. Dakwah multicultural adalah dakwah yang mempunyai ciri menghargai, menghormati budaya dan perbedaan pemahaman tanpa menghilangkan prinsip dan nilai nilai yang Islami.

Adapun pendekatan dakwah pada masyarakat dapat dilakukan dengan dua pendekatan, yaitu melalui pendekatan structural dan pendekatan cultural. ${ }^{132}$ pendekatan structural merupakan pendekatan melalui kekuasaan atau jalur politik. Adapun pendekatan cultural merupakan pendekatan dengan jalur non politis, seperti pemberdayaan dalam bidang sumber daya manusia

132 Ali Aziz., Ilmu Dakwah Edisi Revisi (Jakarta: Kencana, 2004), 348. 
dan proses penegakkan hukum. Dalam konteks pemikiran multikulturalisme dari barat, maka ada keterkaitan dengan pemaparan pendekatan dakwah structural, yang mana dalam multikulturalisme ditekankan juga melalui beragam hal, seperti politik yang terbagi menjadi politik pengakuan, politik identitas baru, politik kesetaraan martabat dan politik perbedaan. Sedangkan dalam pendekatan secara cultural maka dapat diketerkaitkan dengan multikulturalisme akomodatif, dan pragmatism. 